Tetiana Mayorova,

Doctor of Economics, Professor, Kyiv national economic university named after Vadym Hetmana, 54/1Prospect Peremogy, Kyiv, 03057,Ukraine,

ORCID: 0000-0001-9153-8460

ResearcherID: X-8795-2019/

Iuliia Gernego,

Candidate of Sciences (Economics), Kyiv National Economic University named after Vadym Hetman, 54/1, Prospect Peremogy, Kyiv, 03057, Ukraine, ORCID: 0000-0002-4929-0411

ResearcherID: G-7178-2017

Olena Shuplat,

Candidate of Sciences (Economics), Associate Professor, Kyiv National Economic University named after Vadym Hetman, 54/1, Prospect Peremogy, Kyiv, 03057, Ukraine, ORCID: 0000-0001-6318-4714

\title{
FINANCING AND INVESTMENT IN TOURISM AS A DRIVER FOR SUSTAINABLE AND INCLUSIVE GROWTH
}

The article examines the financing and investment aspects of tourism development in Ukraine, considering its importance for sustainable and inclusive growth. The purpose of the article is to identify the main problems of financing and investment development of tourism nowadays. However, the current economic outlook is highly uncertain as the coronavirus pandemic continues to develop. Thereby, there is a higher degree of uncertainty attached to the baseline forecast than under normal circumstances. The current research results make it possible to activate the financial and investment component through the grants attraction.

Keywords: financing, investing, tourism, economic contribution, consolidated budget expenditures, grants.

\section{Thetopic of research relevance.}

The COVID-2019 pandemic is currently highly widespread worldwide, having an increasing impact on tourism development. To date, the United Nations World Tourism Organization (UNWTO) predicts that the decline in industry revenues in 2020 due to the coronavirus pandemic in the global dimension will be $20-30 \%$ or 300-450 billion USD received in 2019. Moreover, the tourism industry can resume its growth rate only in 5-7 years after a pandemic crisis [6]. 
The quarantine measures caused by COVID-2019 have also significantly affected the Ukrainian tour operators activity. The tourism prohibition during the current pandemic crisis, as well as the uncertainty of consumers in the tourism industry after the weakening of quarantine tends to reduce the financial potential for future investment in the tourism industry development. There is an urgent need to find effective ways to reduce pandemia influence on the Ukrainian tourism industryand its sustainability within the current circumstance. This may assist its further development in case of Ukrainian tourism investment attractiveness improvement within the global market.

Formulation of the problem. The industry of tourism is an important source of foreign exchange earnings. Tourism contributes to employment, income growth and the national welfare improvements. In addition, the investment activity of tourism business is a key condition for the successful operation and development of Ukraine both on the national and regional levels. Thereby, it's important to find innovative financial instruments for investment in order to quickly restore the activities of tourism enterprises in Ukraine after the pandemic COVID-2019. This will boost tourism industry sustainability and increase of its attractiveness for consumers of tourism services.

Analysis of recent researches and publications. The tourism industry is traditionally placed among the largest industries worldwide. The concepts of sustainable tourism and inclusive growth are central to many innovative scientific researches nowadays. At the same time, the concept has become rather traditional due to the long history of its development since 1990s, when it was considered by P. Giaretta, N. Guarino, J. A. Clarke, C. Hunter and others. In particular, these researches aimed to estimate the economic sustainability of tourism development. However, understanding the complexity of sustainable tourism is vitally important trend for further researches, including these on social, community and environmental outcomes of tourism financing and financing. In particular, innovation in sustainable tourism and their support system are concerned by M. Aminu, A. Z. B. Muhamad Ludin, A. N. Matori, K. Wan Yusof, L. W. Dano, etc [1; 3]. Some topics on crises, sustainable tourism and achieving its critical understanding are identified by D. Weaver, W. Tan, W. Liu, Y. Hu, etc [10]. One of the most significant current discussions in sustainable tourism is its financing and investment, including these process within COVID-19 timeframe. In particular, the financial and investment aspects of development of international tourism are developed by S. Sardak and V. Zhigula [8]. V. Slavoljub and A. Ljiljana considered the primary sources of tourism financing [12]. The COVID-19 impact is studied by R. Fletcher, I. Murray Mas, M. Blázquez-Salom, T. Jamal, C. Budke and others [5; 7].

\section{The main part of research.}

Tourism is considered as one of three priorities within the Global Development Goals (SDG's). In particular, the tourism is among priorities of SDG 8 (Promoting 
sustainable, inclusive and sustainable economic growth, full and productive employment and decent work for everyone), SDG 12 (Sustainable Consumption and Production), SDG 14 (Sustainable use of oceans, seas and marine resources for sustainable development). Thereby, the main task for developing countries should concern the development and implementation of policies to promote sustainable tourism. This will create new jobs, promote local culture and local production [9].

Unfortunately, the current problems related to the global pandemic COVID2019 , forced quarantine and temporary closure of the tourism business reduce financial opportunities and do not contribute to the intensification of investment activities of tourism and recreation enterprises in Ukraine.

As the result of analysis of the World Tourism and Travel Council (WTTC) study on economic development forecasts for this industry for 185 countries and 25 geographical regions of the world, the current research concerns the fact that tourism has a significant impact on the socio-economic development of most countries and regions worldwide because it creates additional jobs for other areas of activity, primarily transport infrastructure, services, processing industry, etc.

As the result of consideration of Ukrainian tourism industry development before the pandemic COVID-19, the following trends are observed and concluded within the Table 1.

Table 1

The economic contribution of Travel \& Tourism, 2018-2019*

\begin{tabular}{|c|c|c|c|c|c|c|}
\hline \multirow[b]{2}{*}{ Ukraine } & \multicolumn{2}{|c|}{2018} & \multicolumn{4}{|c|}{2019} \\
\hline & 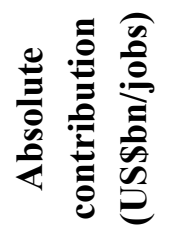 & 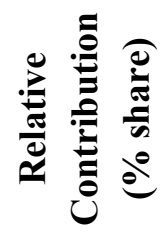 & 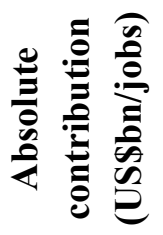 & $\begin{array}{l}\stackrel{60}{E} \\
\stackrel{\vec{E}}{\tilde{E}}\end{array}$ & 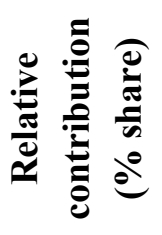 & 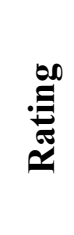 \\
\hline $\begin{array}{l}\text { 1. Direct contribution of T\&T } \\
\text { to GDP }\end{array}$ & 3.06 & 2.1 & 3.24 & 53 & 2.2 & 141 \\
\hline $\begin{array}{l}\text { 2. Total contribution of } \mathrm{T} \& \mathrm{~T} \\
\text { to GDP }\end{array}$ & 8.60 & 6.0 & 8.69 & 145 & 5.9 & 143 \\
\hline $\begin{array}{l}\text { 3. Direct contribution of T\&T } \\
\text { to employment }\end{array}$ & 326.70 & 2.0 & 342.00 & 46 & 2.1 & 151 \\
\hline $\begin{array}{l}\text { 4. Total contribution of } \mathrm{T} \& \mathrm{~T} \\
\text { to employment }\end{array}$ & 1035.0 & 6.1 & 1029.00 & 158 & 6.2 & 145 \\
\hline 5. Visitor exports T\&T & 2.17 & 3.2 & 2.25 & 96 & 3.3 & 158 \\
\hline 6. Capital investment T\&T & 405.50 & 1.75 & 439.40 & 32 & 2.3 & 161 \\
\hline
\end{tabular}

Source: [11] 
The table data analysis makes it possible to estimate the situation within the Ukrainian tourism industry as the stable one. In particular, the tourism industry direct contribution to Ukrainian GDP (value added from accommodation, recreation, related industries) increased from 3.06 to 3.24 billion USD in 2019. According to the indicator of the absolute value of the total contribution of T\&T to GDP formation (in addition to the direct contribution, intersectoral relations, capital investments, government expenditures are taken into account), Ukrainian tourism industry also increased from $\$ 8.6$ to $\$ 8.7$ billion. USD. In addition, during 2019, it increased the relative contribution of $\mathrm{T} \& \mathrm{~T}$ in job creation from $6.1 \%$ to $6.2 \%$, providing $1,029.0$ thousand jobs. The international tourists generated a cash flow of $\$ 2.25$ billion. USD $(3.3 \%$ of exports) during 2019. In case of T\&T capital investment indicator consideration, it increased in absolute terms from $\$ 405.5$ billion to $\$ 440.0$ billion. USD and from $1.75 \%$ to $2.3 \%$ in relative terms in 2019 .

Sustainable development of tourism is impossible without sufficient capital investment in the industry. As the result of the distribution of capital investment by type of economic activity analysis from 2016 to 2019 (Table 2), we observe rather insignificant amounts of capital expenditures financing, which are typical for enterprises within the tourism industry from $0.7 \%$ in 2016 to $1.15 \%$ in 2019 .

Table 2

Capital investments of tourism industry representativesduring 2016-2019 years*

\begin{tabular}{|l|c|c|c|c|c|}
\hline \multicolumn{1}{|c|}{ Indicator } & $\mathbf{2 0 1 5}$ & $\mathbf{2 0 1 6}$ & $\mathbf{2 0 1 7}$ & $\mathbf{2 0 1 8}$ & $\mathbf{2 0 1 9}$ \\
\hline $\begin{array}{l}\text { 1. Capital investments (total Ukrainian } \\
\text { capital investments), million UAH }\end{array}$ & $\mathbf{2 5 1 1 5 4}$ & $\mathbf{3 2 6 1 6 4}$ & $\mathbf{5 7 8 0 4 7}$ & $\mathbf{5 2 6 3 4 2}$ & $\mathbf{5 8 4 4 4 9}$ \\
\hline $\begin{array}{l}\text { 2. Capital investments in tourism, million } \\
\text { UAH }\end{array}$ & $\mathbf{1 9 2 0 , 7}$ & $\mathbf{2 2 3 3 , 7}$ & $\mathbf{3 0 6 2 , 9}$ & $\mathbf{5 2 2 1 , 2}$ & $\mathbf{6 7 1 5 , 2}$ \\
\hline $\begin{array}{l}\text { 2.1. Temporary accommodation and catering, } \\
\text { million UAH }\end{array}$ & 970,0 & 1438,1 & 1591,4 & 1903,6 & 2756,5 \\
\hline Temporary accommodation, million UAH & 542,8 & 725,4 & 904,7 & 934,6 & 968,7 \\
\hline $\begin{array}{l}\text { Food and beverage service activities, million } \\
\text { UAH }\end{array}$ & 427,2 & 712,7 & 686,7 & 969,0 & 1787,8 \\
\hline $\begin{array}{l}\text { 2.2. Arts, sports, entertainment and recreation, } \\
\text { million UAH }\end{array}$ & 921,4 & 795,6 & 1471,5 & 3317,6 & 3958,7 \\
\hline $\begin{array}{l}\text { 3. The share of capital investments mastered } \\
\text { by tourism enterprises in Ukraine, } \%\end{array}$ & $\mathbf{0 , 7 6}$ & $\mathbf{0 , 6 8}$ & $\mathbf{0 , 5 3}$ & $\mathbf{0 , 9 9}$ & $\mathbf{1 , 1 5}$ \\
\hline $\begin{array}{l}\text { 3.1. The share of capital investments mastered } \\
\text { by enterprises for temporary accommodation } \\
\text { and catering to the general volume in the } \\
\text { country, \% }\end{array}$ & 0,39 & 0,44 & 0,28 & 0,36 & 0,47 \\
\hline $\begin{array}{l}\text { 3.2. The share of mastered capital investments } \\
\text { by enterprises in the field of art, entertainment } \\
\text { and recreation to the general. volume in the } \\
\text { country, \% }\end{array}$ & 0,37 & 0,24 & 0,25 & 0,63 & 0,68 \\
\hline
\end{tabular}

Source: [4] 
Thus, the above-mentioned data show us some recovery of capital investment by tourism industry representatives during 2016-2019 years.

However, in case of public funding for tourism industry consideration, the share of consolidated budget expenditures over the past 5 years was about $2.5 \%$ (Table 3 ).

Table 3

The share of expenditures on tourism in the total expenditures of the consolidated budget during 2015-2019 years, \%*

\begin{tabular}{|l|c|c|c|c|c|}
\hline \multicolumn{1}{|c|}{ Indicator } & $\mathbf{2 0 1 5}$ & $\mathbf{2 0 1 6}$ & $\mathbf{2 0 1 7}$ & $\mathbf{2 0 1 8}$ & $\mathbf{2 0 1 9}$ \\
\hline $\begin{array}{l}\text { Total for economic activity in the field of } \\
\text { tourism, hotel, sanatorium and resort facilities; } \\
\text { preservation of the reserve fund; spiritual and } \\
\text { physical development }\end{array}$ & 2,59 & 2,21 & 2,51 & 2,53 & 2,48 \\
\hline Total for other state functions & 97,41 & 97,79 & 97,49 & 97,47 & 97,52 \\
\hline General & 100 & 100 & 100 & 100 & 100 \\
\hline
\end{tabular}

Source: [2]

Unfortunately, in the context of the COVID-2019 pandemic in April 2020, the Ukrainian Government had to reduce public spending, in particular, the expenditures to support the development of tourism in Ukraine. Public funding for the following projects has been canceled, namely: «Opening the tourism industry potential in Ukraine» (240 million UAH) and «Cross-linking the country - a youth mobility project» (500 million UAH).

Considering the current situation in the tourism industry, it is necessary to intensify work to attract additional funding from external sources for the tourism industry further development. One of the possible ways to develop tourism infrastructure is to attract donor funds in the form of grants, namely programs to finance certain projects by national, regional or international funds. For example, in the United States or Australia, tourism grants are awarded at two levels: federal and state. There are also similar national and regional programs in other developed countries. Unfortunately, such development tools are not widespread in Ukraine. The single governmental program, which is similar in some respects to the donor fund supporting grant initiatives, is the State Fund for Regional Development. However, this fund does not prioritize the development of tourism or business in general. It funds other regional initiatives of local communities, including the repair of water mains, hospitals, schools and kindergartens, etc.

Previously, the state allocated funding for the development of tourism within the framework of national regional programs, which included the promotion of the tourist product at the national and international levels. In particular, the state funded participation in exhibitions, presentations at the regional level, seminars for tour 
operators and travel agents, for representatives of green tourism. However, in recent years, no funding has been allocated from state funds for the development of tourism.

On our point of view, the EU grants seem to be among the most important tools to finance investment projects for the development of tourism enterprises within the COVID-2019 pandemic crisis. The European Union regularly funds various projects aimed at economic development, including tourism. At the same time, the development of tourism in Ukraine is considered by Europeans as one of their priorities. Therefore, the European Union regularly announces competitions to open the possibilities for funding attraction, including for projects related to tourism development.

Primarily, it is a program of cross-border and trans-border cooperation. Ukraine participates in 4 cross-border cooperation programs within its framework, namely: Black Sea Basin Program; «Ukraine-Romania»; «Ukraine-Poland-Belarus»; «UkraineHungary-Slovakia-Romania».

The Black Sea Basin Program deserves special attention. Its priority is the joint development of entrepreneurship in the field of tourism. Only regions of the Black Sea states directly adjacent to the Black Sea can participate in the program. The list of Black Sea states includes Greece, Moldova, Armenia and Azerbaijan, with the exception of Russia.

Another effective way to attract funding is public-private partnership. Such mechanism is provided for the rational use, protection and reproduction of tourist resources, de-shadowing of tourist activities, balancing public and private interests in tourism and resorts, preservation and effective use of natural areas of resorts and natural healing resources, ensuring availability and transparency of information on tourist resources and sub objects of tourist activity. An important condition for the development of public-private partnership in the field of tourism is the presence of clearly defined interests of the partnership participants, including its final users tourists.

However, the effectiveness of these measures is possible only with the full withdrawal of Ukrainian quarantine. It is also important to intensify the activities of the State Agency for Tourism Development. It is important to create a favorable investment environment in Ukraine for tourism enterprises that have lost their income due to COVID-2019.

It is reasonable to propose reduction of investment-oriented tax burden, including the following activities: to encourage investment in new projects through tax holidays, tax investment deductions, as well as investment loans. It is reasonable to restore tax holidays for start-ups with foreign investment; to develop the practice of free (preferential) connection of tourist institutions to all types of communications; to restore the zero VAT rate for tourism enterprises that export services. This will reduce the price of services and increase the number of tourists, increase sales of tourist services and additional consumption of goods and services by tourists in excess of 
those provided by the tour operator. One more possibility is to introduce a reduced VAT rate for hotels and other accommodation establishments that provide hotel services that have qualified for compliance with a certain category.

Conclusion. The quarantine measures caused by COVID-2019 have significantly affected the activities of tour operators worldwide. The prohibition on tourism in a pandemic, as well as the uncertainty of consumers of tourism services after the weakening of quarantine will reduce the financial potential for future investment in the development of the industry. Potential tourism opportunities in Ukraine are endless. However, the lack of budget funding due to inconsistencies in public financial policy in the field of tourism, fragmented government and imperfect legislation, lack of strategies and programs for tourism and resorts, as well as territorial losses and hostilities reduce investment activity of tourism enterprises.

Considering the fact that traditional methods and tools of investment activities financial support do not ensure the efficient and sustainable development of tourism, there is a need to find new mechanisms to attract funds to the industry. It is reasonable to consider EU grants, public-private partnership, intensification of state investment policy in the field of tourism as the most effective instruments for financing the investment development of the tourism sector.

\section{REFERENCES}

1. Aminu, M., Muhamad Ludin, A. Z. B., Matori, A. N., Wan Yusof, K., Dano, L. W., \& Chandio, I. A. (2013). A spatial decision support system (SDSS) for sustainable tourism planning in Johor Ramsar sites, Malaysia. Environmental Earth Science, 70, 1113-1124. doi:10.1007/s12665-012-2198-6

2. Annual report on the execution of the State Budget of Ukraine 2016 - 2019. All rights reserved. Retrieved from https://www.treasury.gov.ua/ua/filestorage/richnij-zvit-pro-vikonannya-derzhavnogo-byudzhetu-ukrayini-za-2019-rik

3. Bramwell, B., \& Lane, B. (2012). Towards innovation in sustainable tourism research? Journal of Sustainable Tourism, 20(1), 1-7.10.1080/09669582.2011.641559

4. Capital investments by types of economic activity for 2010-2019All rights reserved. Retrieved from http://www.ukrstat.gov.ua/operativ/operativ2013/ibd/ibd_rik/ ibd_u/ki_rik_u_e_bez.htm

5. Fletcher, R., Murray Mas, I., Blázquez-Salom, M., \& Blanco-Romero, A. (2020). Tourism, degrowth, and the COVID-19 Crisis. Political Ecology Network, 24 March 2020. https://politicalecologynetwork.org/2020/03/24/tourism-degrowth-and-thecovid-19-crisis/.

6. International Tourist Arrivals Could Fall by $20-30 \%$ in 2020 . Retrieved from: https://www.unwto.org/news/international-tourism-arrivals-could-fall-in-2020 
7. Jamal, T., \& Budke, C. (2020). Tourism in a world with pandemics: localglobal responsibility and action. Journal of Tourism Futures, ahead-of-print(ahead-ofprint) https://www.emerald.com/insight/content/doi/10.1108/JTF-02-20200014/full/pdf. doi: 10.1108/JTF-02-2020-0014

8. Sardak S., Zhigula V. (2019), «Financial and investment aspects of development of international tourism», Journal Eastern Europe: economic, business and management, vol 4 (21), Retrieved from:https://www.researchgate.net/ publication/335541092_Finansovye_i_investicionnye_aspekty_razvitia_mezdunarodn ogo_turizma_Financial_and_investment_aspects_of_development_of_international_to urism?enrichId=rgreq-1485c2895df76cc185b4818789fc4b75XXX\&enrichSource=Y292ZXJQYWdlOzMzNTU0MTA5MjtBUzo3OTg0MjM0ND M4NDEwMjRAMTU2NzM3MDM5MTIzNw\%3D\%3D\&el=1_x_2\&_esc=publicatio nCoverPdf

9. Sustainable Development Goals. Retrieved from: http://www.un.org.ua/ua/ tsili-rozvytku-tysiacholittia/tsili-staloho-rozvytku

10. Tan, W. K., Liu, W. C., \& Hu, Y. N. (2012). Finding the crucial factors for sustainable development of rural-based tourist destinations: Using Nanzhuang, Taiwan as a case study. Service Business, 7, 623-640. doi:10.1007/s11628-012-0178-2

11. Travel \& Tourism Economic Impact 2020 Ukraine. All rights reserved. Retrieved from https://wttc.org/Research/Economic-Impact

12. Vujović Slavoljub, Arsić Ljiljana (2018): FINANCING IN TOURISM Basic Sources of Financing the Accommodation Offer. In the Book: Finance and insurance sector industry. Publisher: Silver and Smith Publishers, London, UK. The seventh international scientific conference: EMPLOYMENT, EDUCATION AND ENTREPRENEURSHIP, Belgrade, Serbia 18-20 October 2018. Retrieved from: https://www.researchgate.net/publication/330493322_Financing_in_Tourism_Basic_ Models_of_Financing_the_Accommodation_Offer/link/5d1da168a6fdec2462bdd410/d ownload 